\title{
Incontinence in Late-Onset Pompe Disease: An Underdiagnosed Treatable Condition
}

\author{
Gauthier Remiche $^{\mathrm{a}, \mathrm{b}} \quad$ Anne-Geneviève Herbaut ${ }^{\mathrm{b}}$ Dario Ronchic ${ }^{c}$ Costanza Lamperti ${ }^{\mathrm{d}}$ \\ Francesca Magric Maurizio Moggio ${ }^{c}$ Nereo Bresolin ${ }^{c}$ Giacomo P. Comic \\ ${ }^{a}$ Fonds Erasme pour la Recherche Scientifique, and ${ }^{b}$ Department of Neurology, Hôpital Erasme, Université Libre \\ de Bruxelles, Brussels, Belgium; ' $D$ Dino Ferrari Centre, Department of Neurological Sciences, University of Milan,

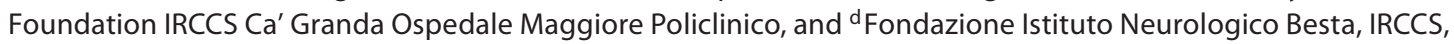 \\ Milan, Italy
}

Dear Sir,

Late-onset Pompe disease (LOPD) is an autosomal recessive multisystemic lysosomal storage disease caused by acid alpha-glucosidase (GAA) deficiency [1-5]. Incidence of Pompe disease varies between $1: 40,000$ and $1: 156,000$ [6-8].

Except in myotonic dystrophy type 1 (DM1) [9-12], incontinence is rarely reported in myopathies [13-15]. Nevertheless, it is a disabling condition in social as well as in professional life [16]. LOPD patients generally have nonhomogeneous muscle involvement (e.g. predominance of atrophy on the posterior compartment of the femoral muscles) [17].

To the best of our knowledge, incontinence has been reported in only 4 LOPD patients (2 urinary and 2 fecal) [18, 19]. Bernstein et al. [19] reported the case of an LOPD incontinent patient with subjective improvement after 3 months of enzyme replacement therapy (ERT). Pathophysiologic hypotheses for incontinence in myopathies include striated and smooth pelvic floor muscle as well as lower motor neuron or autonomic involvement [9-11, 14].

We aimed to assess the prevalence of fecal and urinary incontinence in LOPD and to determine if incontinent patients presented a more severe phenotype. We fo- cused our study on patients with incontinence definitely attributable to LOPD and describe in detail a patient who recovered from his incontinence after ERT. We emphasize the need to look for incontinence in LOPD and to perform the appropriate workup.

\section{Materials and Methods}

From our previously described LOPD cohort [20], we studied only patients being clinically revisited $(n=20)$. Inclusion criteria for LOPD diagnosis were positivity for at least 2 of the following criteria: low GAA enzyme assay (<30\%) [8], vacuolar myopathy and/or increased acid-phosphatase and/or periodic acid-Schiff stain and double GAA gene mutation.

We systematically asked the patients if they had urinary or fecal incontinence, diarrhea or constipation. Main causes of incontinence such as central nervous system disease, peripheral nerve disease, dysautonomia or pelvic surgery were systematically and reasonably excluded by standardized detailed anamnesis and clinical examination in each patient. Women were asked to disclose their maternity status, and in men prostatism was assessed. The main risk factors for incontinence were also assessed (as previously described) [16].

We classified patients into 3 categories: definite, possible or no incontinence related to LOPD (definite: presence of incontinence without any other potential causes such as multiple deliveries or prostatic symptoms, or improvement due only to ERT; possible: presence of incontinence with other potential etiologies and no clinical response to ERT if administered).

Quality of life (QoL) was assessed by the SF-36 questionnaire that was previously validated in QoL assessment of LOPD patients [21]. We compared the demographic and phenotypic data of the group having no incontinence with that having definite incontinence by using the MannWhitney test.

ERT was administered intravenously, in 4 patients, following recommendations of the manufacturer (1/2 weeks; $20 \mathrm{mg} / \mathrm{kg})$. In a 34-year-old male patient (P1), a complete fecal incontinence workup was performed before treatment and 1 year after starting ERT; it included pelvic floor electromyography (EMG), anorectal manometry, and pelvic magnetic resonance imaging (MRI).

The study was in accordance with local ethical committee recommendations.

\section{KARGER}

Fax +4161306 1234 E-Mail karger@karger.ch www.karger.com www.karger.com/ene
Gauthier Remiche, MD

Neurologie, ULB Erasme 808 Route de Lennik

BE-1070 Brussels (Belgium)

Tel. +32 255539 92, E-Mail gauthier.remiche@erasme.ulb.ac.be 


\section{Results}

Out of 20 patients assessed, 9 (45\%) had no incontinence, $6(30 \%)$ had incontinence possibly attributable and 5 (25\%) definitely attributable to LOPD (definite incontinence subgroup) (table 1). No patients in the definite subgroup disclosed any risk factors for incontinence.

In the definite incontinence subgroup, 2 of the 3 ERT-treated patients showed an improvement of their incontinence (the other did not but had started ERT only 3 months before our assessment). No statistically significant difference was found between the latter group and the group without incontinence, using the Mann-Whitney test for sex distribution, age at assessment, duration of the disease, limb muscular strength and respiratory status. Only QoL assessed by the SF-36 questionnaire was statistically significantly better in patients with no incontinence (data not shown) $(\mathrm{p}<0.05)$. Clinical data of patients with definite incontinence due to LOPD are summarized in table 2.

The patient who was fully assessed for fecal incontinence had a 4-limb proximal weakness but was still ambulatory $(\mathrm{P} 1$, table 2). He complained of having had fecal and urinary incontinence for several months at the time of his first assessment. Anal sphincter EMG showed a clear myogenic pattern. Pelvic floor MRI revealed diffuse fatty pelvic floor muscle infiltration and levator ani muscle atrophy but no significant atrophy of the sphincter ani externus. Anorectal manometry showed reduced pressure of both internal and external anal sphincters: internal sphincter basal pressure was $45 \mathrm{~mm} \mathrm{Hg}$ (normal range: $60-70$ ) and external sphincter maximal pressure was $52.5 \mathrm{~mm} \mathrm{Hg}$ (normal range: 110-180). Perineal physiotherapy did not provide improvement. One year later he began ERT. After 3 months of treatment, he observed an improvement in walking and roughly 1 month later he was free of incontinence (improvement remaining after 4 years of follow-up with ERT). Anorectal manometry, performed 1 year after the beginning of ERT, showed significant improvement of internal and external sphincter pressures (58 and 70 $\mathrm{mm} \mathrm{Hg}$, respectively: increase of 28.9 and $33.3 \%$ ), the first measurement being related to smooth muscles. The patient's motor and respiratory conditions were stabilized with ERT.

\section{Discussion}

For the first time, to the best of our knowledge, we estimate the prevalence of incontinence reasonably due to LOPD to be as high as $25 \%$. These patients had no other etiologies or risk factors for incontinence.

The fecal incontinence rate in the general population varies regarding age and sex. Under the age of 70 years, the maximal rate reported is $14 \%$ [22]; in our small sample (none were more than 70 years old), we observed a rate of $30 \%(6 / 20)$ including 2 young male patients ( 28 and 31 years old) without significant limb or respiratory involvement (P4 and P5, respectively, table 2).

Table 1. Findings from the LOPD patient cohort assessed for incontinence

\begin{tabular}{|c|c|}
\hline \multicolumn{2}{|l|}{ Characteristics } \\
\hline Patients, $\mathrm{n}$ & 20 \\
\hline \multicolumn{2}{|l|}{ Sex } \\
\hline Male, $\mathrm{n}$ (age at assessment, years) & 13 (median: 37; min: 23; max: 66) \\
\hline Female, $\mathrm{n}$ (age at assessment, years) & 7 (median: 46; min: 34; max: 64) \\
\hline Sex ratio & 1.9 \\
\hline Mean age \pm SD at assessment, years & $44.8 \pm 13.6$ \\
\hline Definite incontinent patients due to LOPD, n (\%) & total: 5 (25), M: 4 (31), F: 1 (14) \\
\hline ERT & yes no \\
\hline Fecal incontinence & $2(1 \mathrm{M}, 1 \mathrm{~F}) \quad 2(\mathrm{M})$ \\
\hline Double incontinence (fecal and urinary) & $1(\mathrm{M})$ \\
\hline Incontinent patients improved by ERT, n & $2(1 \mathrm{M}, 1 \mathrm{~F})$ \\
\hline
\end{tabular}

Demographic data of our cohort of LOPD patients and distribution of the subgroup with definite incontinence due to LOPD. $\min =$ minimum, $\max =\operatorname{maximum}$, $\mathrm{M}=$ male, $\mathrm{F}=$ female.

Table 2. Clinical data of the LOPD patients having incontinence definitely attributable to LOPD

\begin{tabular}{|c|c|c|c|c|c|c|c|c|c|c|c|c|}
\hline \multirow{2}{*}{$\begin{array}{l}\text { Definite } \\
\text { incontinent } \\
\text { patient sub- } \\
\text { group }\end{array}$} & \multirow{2}{*}{$\begin{array}{l}\text { Type of } \\
\text { in- } \\
\text { continence }\end{array}$} & \multirow[t]{2}{*}{ Sex } & \multicolumn{4}{|l|}{ ERT } & \multirow{2}{*}{$\begin{array}{l}\text { Age at } \\
\text { assess- } \\
\text { ment } \\
\text { (years) }\end{array}$} & \multirow{2}{*}{$\begin{array}{l}\text { Disease } \\
\text { duration (time } \\
\text { between first sym- } \\
\text { tom and asses- } \\
\text { ment) (years) }\end{array}$} & \multirow{2}{*}{$\begin{array}{l}\text { Walton } \\
10 \text {-item } \\
\text { score }\end{array}$} & \multirow{2}{*}{$\begin{array}{l}\text { Forced vital } \\
\text { capacity } \\
\text { (\% of } \\
\text { predicted } \\
\text { value) }\end{array}$} & \multirow{2}{*}{$\begin{array}{l}\text { As- } \\
\text { sisted } \\
\text { venti- } \\
\text { lation }\end{array}$} & \multirow{2}{*}{$\begin{array}{l}\text { SF-36 } \\
\text { score } \\
(/ 100)\end{array}$} \\
\hline & & & & follow-up & $\begin{array}{l}\text { response for inconti- } \\
\text { nence (timing) }\end{array}$ & $\begin{array}{l}\text { response for limb } \\
\text { strength/disability } \\
\text { (timing) }\end{array}$ & & & & & & \\
\hline P1 & double & M & yes & 4 years & yes (4 months) & yes (3 months) & 34 & 25 & 3 & 40.8 & no & 45 \\
\hline $\mathrm{P} 2$ & fecal & $\mathrm{F}$ & yes & 1 year & yes (6 months) & yes (2 months) & 61 & 16 & 3 & 47 & NINV & 60 \\
\hline P3 & fecal & M & yes & 3 months & no & yes (3 months) & 60 & 25 & 6 & 52 & NINV & 49 \\
\hline $\mathrm{P} 4$ & fecal & M & no & & & & 31 & 11 & 0 & 83 & no & 65 \\
\hline P5 & fecal & M & no & & & & 28 & 8 & 0 & 86 & no & 45 \\
\hline
\end{tabular}

NINV $=$ Noninvasive nocturnal ventilation 
In our cohort, urinary incontinence did not reach higher rates than previously described in the general population [23], but we considered at least for 1 patient, because of the absence of other potential causes and its association with fecal incontinence, that urinary incontinence could be attributable to LOPD (P1, table 2).

As described in other conditions [16], incontinence was statistically associated with a poorer QoL. Moreover, it was mainly found in patients with weaker limb strength and lower vital capacity (not statistically significant). We did not find any additional significant association between incontinence and other phenotype findings, but this could be due to the small size of our sample (lack of power).

Even though, due to the small size of our sample, we are not able to provide definite statistical conclusions, we observed that incontinence was present at all stages of the disease: 2 of the 5 incontinent patients presented walking disability and restrictive syndrome and 2 other young male patients had no significant respiratory or walking limitations (P4 and P5, table 2). In the fully assessed patient (P1, table 2), ERT response to incontinence was, for the first time, confirmed by objective measurements. Striated muscle-dependent functions such as limb strength or respiratory function are improved by ERT [24]. Our result confirmed [19] the enduring improvement of sphincter function by ERT. Accumulation of glycogen in many tissues including smooth muscle is seen in LOPD [25-28]. We demonstrated, by objective measurements, the improvement of internal anal sphincter pressures, a smooth muscle-dependent function, with ERT. This is an additional argument in favor of the presence of glycogen accumulation in the smooth muscle in LOPD patients and provides hope for its treatability. Further studies are mandatory to confirm this result and their outcome might lead to an increased indication for ERT to prevent smooth muscle deterioration such as, for example, in cerebral ar- tery disease which can lead to aneurism rupture [29-31].

Recognition of incontinence in LOPD patients is important as patients are generally reluctant to complain of this problem [16]. Moreover, as incontinence is seen in patients having a poor QoL but also in the early stages of the disease, it should be an additional parameter to consider in the decision to start ERT.

In order to recognize incontinence in LOPD patients, we suggest systematically performing appropriate anamnesis and, if positive, to prescribe an ad hoc workup (pelvic EMG, anorectal manometry, pelvic MRI; and if urinary incontinence is present, urodynamic tests and pre/post-micturition bladder ultrasonography).

In conclusion, incontinence is a frequent, probably underdiagnosed, and potentially disabling condition in LOPD (and probably in other neuromuscular disorders). Clinicians should be aware of possible incontinence in these patients as treatments are now available.

\section{References}

1 Kroos MA, Pomponio RJ, Hagemans ML, et al: Broad spectrum of Pompe disease in patients with the same c.-32-13t->g haplotype. Neurology 2007;68:110-115.

$\checkmark 2$ Raben N, Plotz P, Byrne BJ: Acid alpha-glucosidase deficiency (glycogenosis type ii, Pompe disease). Curr Mol Med 2002;2:145166.

3 Engel A, Franzini-Armstrong C: Myology: Basic and Clinical, ed 3. New York, McGrawHill, Medical Pub. Division, 2004.

$\checkmark 4$ Engel AG, Gomez MR, Seybold ME, Lambert EH: The spectrum and diagnosis of acid maltase deficiency. Neurology 1973;23:95106.

$\checkmark 5$ Van den Hout JM, Kamphoven JH, Winkel LP, et al: Long-term intravenous treatment of Pompe disease with recombinant human alpha-glucosidase from milk. Pediatrics 2004; 113:e448-e457.

6 Martiniuk F, Chen A, Mack A, et al: Carrier frequency for glycogen storage disease type ii in New York and estimates of affected individuals born with the disease. Am J Med Genet 1998;79:69-72.

-7 Ausems MG, Verbiest J, Hermans MP, et al: Frequency of glycogen storage disease type ii in The Netherlands: implications for diagnosis and genetic counselling. Eur J Hum Genet 1999;7:713-716.

$\checkmark 8$ van der Ploeg AT, Reuser AJ: Pompe's disease. Lancet 2008;372:1342-1353. $\checkmark 9$ Herbaut AG, Nogueira MC, Panzer JM, Zegers de Beyl D: Anorectal incontinence in myotonic dystrophy: a myopathic involvement of pelvic floor muscles. Muscle Nerve 1992;15:1210-1211.

10 Lecointe-Besancon I, Leroy F, Devroede G, et al: A comparative study of esophageal and anorectal motility in myotonic dystrophy. Dig Dis Sci 1999;44:1090-1099.

11 Abercrombie JF, Rogers J, Swash M: Faecal incontinence in myotonic dystrophy. J Neurol Neurosurg Psychiatry 1998;64:128-130.

12 Sakakibara R, Hattori T, Tojo M, Yamanishi T, Yasuda K, Hirayama K: Micturitional disturbance in myotonic dystrophy. J Auton Nerv Syst 1995;52:17-21.

13 Caress JB, Kothari MJ, Bauer SB, Shefner JM Urinary dysfunction in Duchenne muscular dystrophy. Muscle Nerve 1996;19:819-822.

14 MacLeod M, Kelly R, Robb SA, Borzyskowski M: Bladder dysfunction in Duchenne muscular dystrophy. Arch Dis Child 2003; 88:347-349.

15 Miller TD, Jackson AP, Barresi R, et al: Inclusion body myopathy with Paget disease and frontotemporal dementia (IBMPFD): clinical features including sphincter disturbance in a large pedigree. J Neurol Neurosurg Psychiatry 2009;80:583-584.
16 Alsheik EH, Coyne T, Hawes SK, et al: Fecal incontinence: prevalence, severity, and quality of life data from an outpatient gastroenterology practice. Gastroenterol Res Pract 2012;2012:947694.

17 Laforet P, Nicolino M, Eymard PB, et al: Juvenile and adult-onset acid maltase deficiency in France: genotype-phenotype correlation. Neurology 2000;55:1122-1128.

18 Chancellor AM, Warlow CP, Webb JN, Lucas MG, Besley GT, Broadhead DM: Acid maltase deficiency presenting with a myopathy and exercise induced urinary incontinence in a 68 year old male. J Neurol Neurosurg Psychiatry 1991;54:659-660.

19 Bernstein DL, Bialer MG, Mehta L, Desnick RJ: Pompe disease: Dramatic improvement in gastrointestinal function following enzyme replacement therapy. A report of three later-onset patients. Mol Genet Metab 2010; 101:130-133.

20 Remiche G, Ronchi D, Lamperti C, et al: Adult form type ii glycogen storage disease in a northern Italy population: phenotype characterization, early diagnosis and prognostic determinants. Neurology 2008; 70:A309.

21 Hagemans ML, Janssens AC, Winkel LP, et al: Late-onset Pompe disease primarily affects quality of life in physical health domains. Neurology 2004;63:1688-1692. 
22 Whitehead WE, Borrud L, Goode PS, et al: Fecal incontinence in US adults: epidemiology and risk factors. Gastroenterology 2009; 137:512-517, 517 e1-e2.

-23 Markland AD, Richter HE, Fwu CW, Eggers P, Kusek JW: Prevalence and trends of urinary incontinence in adults in the United States, 2001 to 2008. J Urol 2011;186:589593.

24 van der Ploeg AT, Clemens PR, Corzo D, et al: A randomized study of alglucosidase alfa in late-onset Pompe's disease. N Engl J Med 2010;362:1396-1406.
25 Shotelersuk V, Shuangshoti S, Chotivitayatarakorn $\mathrm{P}$, et al: Clinical, pathological, and electron microscopic findings in two Thai children with Pompe disease. J Med Assoc Thai 2002;85(suppl 1):S271-S279.

26 Teng YT, Su WJ, Hou JW, Huang SF: Infantile-onset glycogen storage disease type ii (Pompe disease): report of a case with genetic diagnosis and pathological findings. Chang Gung Med J 2004;27:379-384.

27 Thurberg BL, Lynch Maloney C, Vaccaro C, et al: Characterization of pre- and post-treatment pathology after enzyme replacement therapy for Pompe disease. Lab Invest 2006; 86:1208-1220.

-28 Bijvoet AG, Van Hirtum H, Vermey M, et al: Pathological features of glycogen storage disease type ii highlighted in the knockout mouse model. J Pathol 1999;189:416-424.
29 Sacconi S, Bocquet JD, Chanalet S, Tanant V, Salviati L, Desnuelle C: Abnormalities of cerebral arteries are frequent in patients with late-onset Pompe disease. J Neurol 2010;257: 1730-1733.

30 Laforet P, Petiot P, Nicolino M, et al: Dilative arteriopathy and basilar artery dolichoectasia complicating late-onset Pompe disease. Neurology 2008;70:2063-2066.

31 Winkel LP, Hagemans ML, van Doorn PA, et al: The natural course of non-classic Pompe's disease; a review of 225 published cases. J Neurol 2005;252:875-884. 